\title{
COMPARATIVE GROWTH, PRODUCTIVITY, QUALITY AND PROFITABILITY OF PLANT AND RATOON CROP OF SUGARCANE UNDER DIFFERENT PIT DIMENSIONS
}

\author{
Mubashar Nadeem",*, Riaz Ahmad', Asif Tanveer ${ }^{1}$ and Muhammad Yaseen² \\ ${ }^{1}$ Department of Agronomy, University of Agriculture Faisalabad-38040, Pakistan; ${ }^{2}$ Institute of Soil and \\ Environmental Sciences, University of Agriculture Faisalabad-38040, Pakistan. \\ *Corresponding author's e-mail: mubasharuaf@ hotmail.com
}

\begin{abstract}
Demand for sugar in Pakistan is increasing day by day while the scope for increasing area of sugarcane is limited. Conventional sowing techniques/planting patterns are one of imperative reason for low productivity of sugarcane in Pakistan. Therefore, we assumed the yield, quality and economics of sugarcane under square and round pit planting techniques. During 2013-15 and 2015-16 at Faisalabad, the experiment was arranged in randomized complete block design. Planting techniques were comprised of $45 \mathrm{~cm}$ spaced square pits having area $90 \mathrm{~cm} \times 90 \mathrm{~cm}, 45 \mathrm{~cm}$ spaced round pits having diameter $90 \mathrm{~cm}, 60 \mathrm{~cm}$ spaced square pits having area $90 \mathrm{~cm} \times 90 \mathrm{~cm}, 60 \mathrm{~cm}$ spaced round pits having diameter $90 \mathrm{~cm}, 75 \mathrm{~cm}$ spaced square pits having area $90 \mathrm{~cm}$ $\times 90 \mathrm{~cm}, 75 \mathrm{~cm}$ spaced round pits having diameter $90 \mathrm{~cm}, 90 \mathrm{~cm}$ spaced square pits having area $90 \mathrm{~cm} \times 90 \mathrm{~cm}$ and $90 \mathrm{~cm}$ spaced round pits having diameter $90 \mathrm{~cm}$. After the harvest of the first-year crop, the field was kept as ratoon crop for $2^{\text {nd }}$-year trials. Maximum plant height $374.66 \mathrm{~cm}$ and $323.41 \mathrm{~cm}$ was attained when sugarcane was planted in $90 \mathrm{~cm}$ spaced square pits having area a $90 \mathrm{~cm} \times 90 \mathrm{~cm}$ in plant and ratoon crop, respectively. The highest unstripped cane yield (158.08 t/ha and 128.78 $\mathrm{t} / \mathrm{ha}$ ) and stripped cane yield ( $134.88 \mathrm{t} / \mathrm{ha}$ and $101.51 \mathrm{t} / \mathrm{ha})$ was obtained from sugarcane planted at $45 \mathrm{~cm}$ spaced square pits having an area $90 \mathrm{~cm} \times 90 \mathrm{~cm}$ in plant and ratoon crop, respectively. Moreover, this treatment gave maximum net return of Rs.177370/ha, net field benefits of Rs.347819/ha and benefit-cost ratio of 1.57.
\end{abstract}

Keywords: Sugar crop, planting methods, stripped cane yield, net returns, pit plantation.

\section{INTRODUCTION}

Sugarcane is an important profitable sugar crop of Pakistan. Pakistan ranks at the $4^{\text {th }}$ and $8^{\text {th }}$ position by the area under cultivation and sugar production, respectively across the globe (FAO, 2012). It shares $3.2 \%$ in value-added agriculture and $0.6 \%$ in GDP (Govt. of Pakistan, 2016). The cultivated area under sugarcane during 2015-16 was $1.132 \mathrm{~m}$ ha that showed a decline of $0.8 \%$ from previous year $(1.141 \mathrm{~m} \mathrm{ha})$ (Govt. of Pakistan, 2016). On the contrary, total production during 2015-16 was 65.5 million tonnes, thus showed an increase of $4.2 \%$ from the production of the previous year (62.8 million tonnes). Pakistan's average stripped cane yield is much lower than other sugarcane growing countries across the world. The harvestable yield potential of the current gene pool of sugarcane cultivars is more than $150 \mathrm{t} / \mathrm{ha}$. However, our national average yield is $60 \mathrm{t} / \mathrm{ha}$ which is far below than its genetic potential. Many of the advanced countries like Brazil, India, China, USA and Australia have their national average yield ranging from $80-100$ t/ha (FAO, 2012). The affluent inputs, natural disasters, insufficient water application, and weeds establishment, along with poorly managed ratoon and improper planting patterns are main reasons for low production of sugarcane (Ahmad et al., 2014; Nazir et al., 2013).
Hence, there is a dire need to search out for new planting techniques of sugarcane planting to achieve optimum planting density that ensures productive utilization of available farm resources. Different planting patterns like $60 \mathrm{~cm}$ spaced single rows, $90 \mathrm{~cm}$ double row strips and $120 \mathrm{~cm}$ apart trench planting are being adopted in Pakistan for enhancing sugarcane yield. Majority of the farming community faces problems by using the conventional method of planting in 60$75 \mathrm{~cm}$ spaced rows that significantly affects the circulation of air and interception of light required for crop growth (Ehsanullah et al., 2011).

Many innovative methods which facilitate inter tillage operations and ensure optimum planting densities for obtaining higher yields have been developed (Ghaffar et al., 2011). Pit planting technique was introduced in early 1990 as an efficient plantation technique which helps to facilitate germination, achieve optimal plant population and increased sugar recovery. Maqsood et al. (2005) opined that more cane production of sugarcane was observed in $50 \mathrm{~cm}$ spaced pits $(100 \mathrm{~cm} \times 100 \mathrm{~cm})$ than the conventional method. Pit planting improved the assimilatory characters, like crop growth rate, leaf area index and increased the cane yield compared to conventional planting method improved germination and increased millable canes (Singh et al., 2009; Sureka et al. 2009 and Chand et al., 2011). 
Sugarcane's ratooning potential is one of the most necessary characters from farmer point of view (Chattha and Ehsanullah, 2003). Keeping the sugarcane crop as ratoon is economically a viable option for the growers as its cost of production is $25-30 \%$ less than the plant crop. Moreover, huge quantities of seed, irrigation water, labor force and the cost of land preparation are also saved (Shukla et al., 2013). In Pakistan, ratoon sugarcane occupies more than $50 \%$ of the total cropped area under sugarcane. Its contribution (25-30\%) in total cane production is quite significant (Rehman and Ehsanullah, 2008). Though the potential of ratoon crop is naturally $10-30 \%$ lower than the newly planted crop, however, still a comparable yield percentage can still be realized and achieved by taking appropriate care of the ratoon crop (Aamer et al., 2017).

Keeping this in view, the present study was planned to estimate the effect of pit planting methods/techniques on emergence, yield, quality and benefit cost analysis of plant and ratoon crop.

\section{MATERIALS AND METHODS}

Site: The field studies were carried out from 2013-16 in the central Punjab region, at research site of the University of Agriculture, Faisalabad (Pakistan). The soil is alluvial in nature and area is canal irrigated. The geographic location of Faisalabad indicates that it lies at $31.5^{\circ} \mathrm{N}$ latitude and $73^{\circ} \mathrm{E}$ longitude with $184.4 \mathrm{~m}$ altitude above sea level. The weather is considered semi-arid with very hot and humid summers and cool dry winter. The summer season starts from the month of April, which lasts up to October, whereas the hottest months of the years are May to July. December to February is known as coldest months of Pakistan. Data was collected from the observatory of Meteorology Cell, located in University of Agriculture, Faisalabad nearest to the research site. Data presented in fig 1 and 2 on monthly average basis.

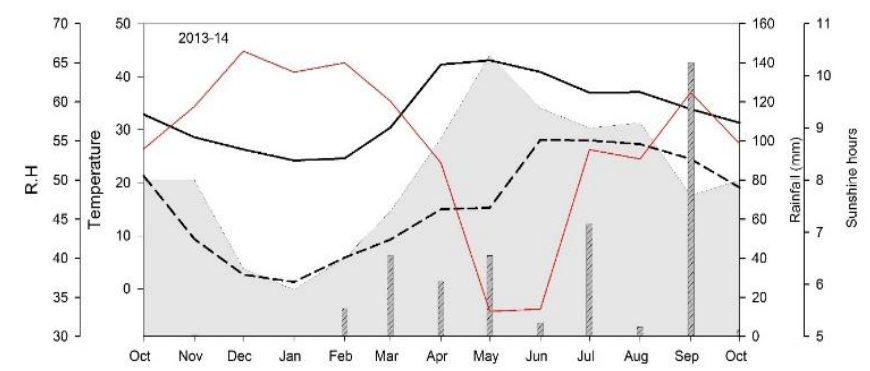

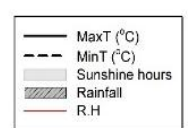

Figure 1. Meteorological data during plant crop season of sugarcane.
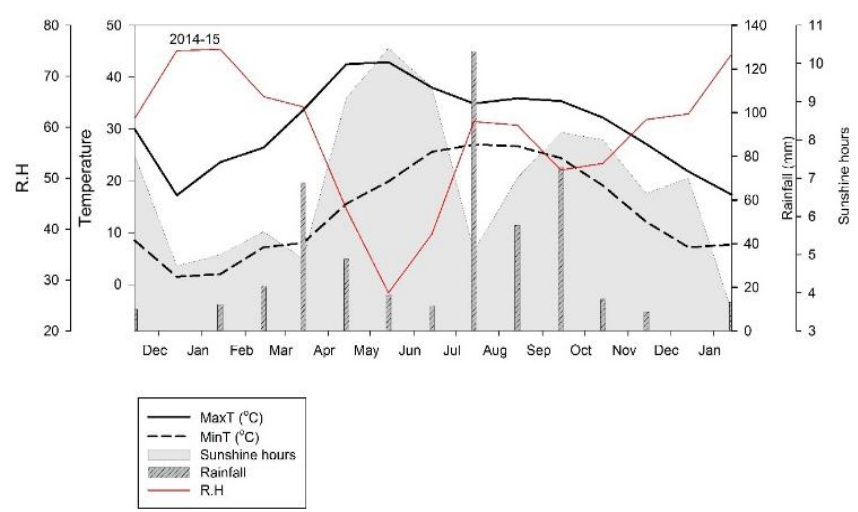

Figure 2. Meteorological data during ratoon crop season of sugarcane.

Soil analysis of experimental site: The composite soil samples from 0-30 cm depth were collected and analyzed for various soil physico-chemical characteristics, prior to the study. Soil samples were taken after harvesting of crop and analyzed for N, P and $\mathrm{K}$. The analysis was carried out in Institute of Soil and Environmental Sciences (ISES). The experimental soil was sandy loam sand percentage 61.8563.12, silt percentage $16.39-19.75$ and clay percentage 19.2920.95 , having $\mathrm{pH}$ from 7.80-7.85, electrical conductivity 1.19-1.21 $\left(\mathrm{dSm}^{-1}\right)$, organic matter 0.79-0.80 (\%), available nitrogen concentration of 0.041-0.043 (\%), available phosphorus 6.88-6.99 (ppm) and available potassium 135-140 (ppm) comprehensive soil analysis is presented in Table 1.

Table 1. Soil analysis of the experimental area.

Soil Characteristics
2013-2015 2015-2016

A. Physical characteristics

\begin{tabular}{lrr} 
Sand \% & 63.12 & 61.85 \\
Silt \% & 19.75 & 16.39 \\
Clay \% & 19.29 & 20.95 \\
B. Chemical analysis & & \\
$\mathrm{pH}$ & 7.80 & 7.85 \\
$\left.\mathrm{EC}_{\mathrm{e}}(\mathrm{dSm})^{-1}\right)$ & 1.21 & 1.19 \\
Organic matter (\%) & 0.79 & 0.80 \\
Available $\mathrm{N}(\%)$ & 0.04 & 0.04 \\
Available Phosphorus $\mathrm{P}_{2} \mathrm{O}_{5}(\mathrm{ppm})$ & 6.99 & 6.88 \\
Available Potassium $\mathrm{K}_{2} \mathrm{O}(\mathrm{ppm})$ & 140.00 & 135.00 \\
\hline
\end{tabular}

Experimental material: The sugarcane was planted on $11^{\text {th }}$ of the September 2013, whereas $2^{\text {nd }}-$ year crop was kept as ratoon crop. Harvesting of plant crop (first year crop) was done on $15^{\text {th }}$ of January 2015, while ratoon (second-year crop) was harvested on $15^{\text {th }}$ February 2016. The planting patterns were as follows; $\mathrm{P}_{1}=45 \mathrm{~cm}$ spaced square pits having an area 90 $\mathrm{cm} \times 90 \mathrm{~cm}, \mathrm{P}_{2}=45 \mathrm{~cm}$ spaced round pits having diameter 90 $\mathrm{cm}, \mathrm{P}_{3}=60 \mathrm{~cm}$ spaced square pits having an area $90 \mathrm{~cm} \times 90$ $\mathrm{cm}, \mathrm{P}_{4}=60 \mathrm{~cm}$ spaced round pits having diameter $90 \mathrm{~cm}$, $\mathrm{P}_{5}=75 \mathrm{~cm}$ spaced square pits having an area $90 \mathrm{~cm} \times 90 \mathrm{~cm}$, 
$\mathrm{P}_{6}=75 \mathrm{~cm}$ spaced round pits having diameter $90 \mathrm{~cm}, \mathrm{P}_{7}=90$ $\mathrm{cm}$ spaced square pits having an area $90 \mathrm{~cm} \times 90 \mathrm{~cm} \mathrm{P}_{8}=90$ $\mathrm{cm}$ spaced round pits having diameter $90 \mathrm{~cm}$. The field was prepared thoroughly following the standard tillage operations. In pit plantation, round pits were mechanical dug up to a depth of $60 \mathrm{~cm}$ using tractor mounted post hole digger. While digging of square pits was done with the help of labor. These pits were then refilled up to $45 \mathrm{~cm}$ depth with the same soil. No hoeing and earthing up operations were carried out. For irrigation purpose, pits in each treatment were connected with one another with small water channel like basin system of irrigation. Water and fertilizer were applied only in pits and not to fallow space left between the pits. Pre-sowing irrigation was given in all pits. Sugarcane's variety CPF-247 was selected as test variety for both years of experiment. Fertilizer was applied at the rate of $165 \mathrm{~kg} \mathrm{~N}$ (urea), $110 \mathrm{~kg} \mathrm{P} \mathrm{ha}^{-1}$ (DAP) and $110 \mathrm{~kg} \mathrm{~K} \mathrm{ha}^{-1}$ (SOP). While in ratoon crop, fertilizer application rate was $30 \%$ more than that of the first-year plant crop. All phosphorus and potash application were done during planting, while nitrogen application was made in three splits: at the time of sowing, tillering, and earthing up. Weeds were controlled by the application of ametryn+ atrazine at $2.5 \mathrm{~kg}$ $\mathrm{ha}^{-1}$. Insect pest population was controlled using the recommended agro-chemicals. Chloropyriphos@ 5 L/ha was applied at first irrigation to prevent termite attack. Observations like, emergence percentage (\%), plant height $(\mathrm{cm})$, internodal length $(\mathrm{cm})$, stalk diameter $(\mathrm{cm})$, un-stripped and stripped yield of cane ( $\mathrm{t} / \mathrm{ha})$, brix (\%), commercial cane sugar $(\%)$, and cane sugar recovery $(\%)$ were recorded following the standard protocols (Spancer and Measde, 1963). While at the end of experiment economic analysis was also analyzed in detail (CIMMYT, 1988).

The statistical analysis of data was made by utilizing Fisher's analysis of variance (Steel et al., 1996). The differences among the treatment's means were estimated through least significance difference (LSD) test through Statistix 10 (Tallahassee, FL 32317) at the probability level $(\mathrm{p}<0.05)$.

\section{RESULTS}

In this study, the planting patterns were compared for emergence percentage, plant height and internodal length of sugarcane (Table 2) for both plant and ratoon crop. It is clear from the table that different planting patterns did not bring any significant change in the emergence percentage of sugarcane. However, emergence percentage of sugarcane ranged between 48 to $49 \%$.

There was significant variation in plant height of sugarcane planted in different pits systems of the plantation. In plant crop (first year crop) the maximum plant height $(374.66 \mathrm{~cm}$ ) was recorded when sugarcane was sown in $\mathrm{P}_{7}$ which was statistically equal to with those of $\mathrm{P}_{8}(374.10 \mathrm{~cm}), \mathrm{P}_{6}(373.99$ $\mathrm{cm}), \mathrm{P}_{3}(373.28 \mathrm{~cm}), \mathrm{P}_{1}(372.92)$ and $\mathrm{P}_{4}(372.90 \mathrm{~cm})$, whereas, minimum plant height $(369.99 \mathrm{~cm})$ was observed when sugarcane was planted at $45 \mathrm{~cm}$ spaced round pits with diameter of $90 \mathrm{~cm}\left(\mathrm{P}_{2}\right)$. In ratoon crop, the highest plant height $(323.41 \mathrm{~cm})$ was achieved in $\mathrm{P}_{7}$ and it was at par with all other planting methods under study except $\mathrm{P}_{2}(317.74 \mathrm{~cm})$.

The internodal length sums up to contribute towards the total cane length, thus influencing the cane growth and yield. The maximum internodal length was observed when sugarcane was sown as plant crop in $\mathrm{P}_{8}(12.08 \mathrm{~cm})$ (Table 2). This treatment was at par with all other planting systems except $\mathrm{P}_{2}$ $(10.91 \mathrm{~cm})$ during the first year. In ratoon crop, the highest internodal length $(10.11 \mathrm{~cm})$ was observed when sugarcane was sown in the pattern of $\mathrm{P}_{8}$. This treatment was statistically equal to all other planting patterns except $\mathrm{P}_{3}(9.52 \mathrm{~cm})$.

Table 2. Effect of different planting patterns on emergence percentage, plant height and internodal length of sugarcane.

\begin{tabular}{|c|c|c|c|c|c|}
\hline \multirow{2}{*}{$\begin{array}{l}\text { Planting } \\
\text { patterns }\end{array}$} & \multirow{2}{*}{$\begin{array}{l}\text { Emergence percentage } \\
\text { Plant crop 2013-15 }\end{array}$} & \multicolumn{2}{|c|}{ Plant height $(\mathrm{cm})$} & \multicolumn{2}{|c|}{ Internodal length $(\mathrm{cm})$} \\
\hline & & $\begin{array}{c}\text { Plant crop } \\
\text { 2013-15 } \\
\end{array}$ & $\begin{array}{c}\text { Ratoon crop } \\
2015-16 \\
\end{array}$ & $\begin{array}{c}\text { Plant crop } \\
\text { 2013-15 } \\
\end{array}$ & $\begin{array}{c}\text { Ratoon crop } \\
2015-16\end{array}$ \\
\hline $\mathrm{P}_{1}$ & 49.00 & $372.92 \mathrm{abc}$ & $318.92 \mathrm{ab}$ & $11.08 \mathrm{ab}$ & $9.93 \mathrm{a}$ \\
\hline $\mathrm{P}_{2}$ & 49.00 & $369.99 \mathrm{c}$ & $317.74 b$ & $10.91 \mathrm{~b}$ & $9.97 \mathrm{a}$ \\
\hline $\mathrm{P}_{3}$ & 48.75 & $373.28 \mathrm{abc}$ & $321.53 \mathrm{ab}$ & $11.05 \mathrm{ab}$ & $9.52 \mathrm{~b}$ \\
\hline $\mathrm{P}_{4}$ & 48.50 & $372.90 \mathrm{abc}$ & $320.87 \mathrm{ab}$ & $11.75 \mathrm{ab}$ & $10.10 \mathrm{a}$ \\
\hline $\mathrm{P}_{5}$ & 48.25 & $370.19 \mathrm{bc}$ & $318.94 \mathrm{ab}$ & $11.54 \mathrm{ab}$ & $9.94 \mathrm{a}$ \\
\hline $\mathrm{P}_{6}$ & 48.00 & $373.99 \mathrm{ab}$ & $321.74 \mathrm{ab}$ & $11.59 \mathrm{ab}$ & $9.96 \mathrm{a}$ \\
\hline $\mathrm{P}_{7}$ & 49.00 & $374.66 \mathrm{a}$ & $323.41 \mathrm{a}$ & $11.23 \mathrm{ab}$ & $9.94 \mathrm{a}$ \\
\hline $\mathrm{P}_{8}$ & 48.25 & $372.92 \mathrm{abc}$ & $318.92 \mathrm{ab}$ & $12.08 \mathrm{a}$ & $10.11 \mathrm{a}$ \\
\hline $\operatorname{LSD}(\mathrm{p} \leq 0.05)$ & N.S & 3.92 & 5.67 & 1.04 & 0.39 \\
\hline
\end{tabular}

$\mathrm{P}_{1} ; 45 \mathrm{~cm}$ spaced square pits having area $90 \mathrm{~cm} \times 90 \mathrm{~cm}, \mathrm{P}_{2} ; 45 \mathrm{~cm}$ spaced round pits having diameter $90 \mathrm{~cm}, \mathrm{P}_{3} ; 60 \mathrm{~cm}$ spaced square pits having area $90 \mathrm{~cm} \times 90 \mathrm{~cm}, \mathrm{P}_{4} ; 60 \mathrm{~cm}$ spaced round pits having diameter $90 \mathrm{~cm}, \mathrm{P}_{5} ; 75 \mathrm{~cm}$ spaced square pits having area $90 \mathrm{~cm} \times$ $90 \mathrm{~cm}, \mathrm{P}_{6} ; 75 \mathrm{~cm}$ spaced round pits having diameter $90 \mathrm{~cm}, \mathrm{P}_{7} ; 90 \mathrm{~cm}$ spaced square pits having area $90 \mathrm{~cm} \times 90 \mathrm{~cm}, \mathrm{P}_{8} ; 90 \mathrm{~cm}$ spaced round pits having diameter $90 \mathrm{~cm}$ 
Nadeem, Ahmad, Tanveer \& Yaseen

Table 4. Effect of different pit planting patterns on average net return, field benefits and benefit-cost ratio of plant and ratoon sugarcane 2013-16 (each value is the average total experimental duration).

\begin{tabular}{lcccccc}
\hline $\begin{array}{l}\text { Planting } \\
\text { patterns }\end{array}$ & $\begin{array}{c}\text { Variable cost } \\
\left(\text { Rs. ha }^{-1}\right)\end{array}$ & Cost $\left(\right.$ Rs. ha $\left.^{-\mathbf{1}}\right)$ & $\begin{array}{c}\text { Gross income } \\
\left(\text { Rs. ha }^{-1}\right)\end{array}$ & $\begin{array}{c}\text { Net return } \\
\left(\text { Rs. ha }^{-1}\right)\end{array}$ & $\begin{array}{c}\text { Net field benefits } \\
\left(\text { Rs. ha }^{-1}\right)\end{array}$ & $\begin{array}{c}\text { Benefit } \\
\text { cost ratio }\end{array}$ \\
\hline $\mathrm{P}_{1}$ & 209338 & 379787 & 487554 & 107767 & 278216 & 1.28 \\
$\mathrm{P}_{2}$ & 138059 & 308508 & 485878 & 177370 & 347819 & 1.57 \\
$\mathrm{P}_{3}$ & 189067 & 359516 & 455297 & 95781 & 266230 & 1.27 \\
$\mathrm{P}_{4}$ & 127262 & 297711 & 443644 & 145933 & 316382 & 1.49 \\
$\mathrm{P}_{5}$ & 175819 & 346268 & 432713 & 86445 & 256894 & 1.25 \\
$\mathrm{P}_{6}$ & 119519 & 289968 & 422400 & 132432 & 302881 & 1.46 \\
$\mathrm{P}_{7}$ & 143718 & 314166 & 389957 & 75790 & 246239 & 1.24 \\
$\mathrm{P}_{8}$ & 104239 & 274688 & 393628 & 118940 & 289389 & 1.43 \\
\hline
\end{tabular}

The results presented in Table 3 further revealed that planting patterns markedly improved cane girth as also observed by (Singh et al., 2009). However, Cane girth was not affected statically in plant crop, while variation in cane diameter was observed only in ratoon crop. The maximum cane diameter $(2.32 \mathrm{~cm})$ of sugarcane was attained in $\mathrm{P}_{8}$. However, it was at par with $\mathrm{P}_{7}(2.31 \mathrm{~cm}), \mathrm{P}_{6}(2.30 \mathrm{~cm})$ and $\mathrm{P}_{5}(2.29 \mathrm{~cm})$. The minimum cane diameter $(2.27 \mathrm{~cm})$ was recorded in $\mathrm{P}_{1}$ followed by those of $\mathrm{P}_{2}(2.28 \mathrm{~cm}), \mathrm{P} 3(2.28 \mathrm{~cm})$ and $\mathrm{P}_{4}(2.28$ $\mathrm{cm})$. Results related to un-stripped cane yield/total biomass showed that panting patterns had a pronounced influence on un-stripped cane yield. In plant cane, maximum un-stripped cane yield was noted in $\mathrm{P}_{1}(158.03 \mathrm{t} / \mathrm{ha})$ followed by $\mathrm{P}_{2}$ (153.25 t/ha). The minimum total biomass was recorded in $P_{7}$ (131.50 t/ha), however, this was statistically equal to $\mathrm{P}_{8}$ (132.44 t/ha). In ratoon crop, the highest unstripped cane yield was observed in $\mathrm{P}_{1}(128.78 \mathrm{t} / \mathrm{ha})$, while the lowest un-stripped cane yield was noticed in $\mathrm{P}_{8}$ (108.84 t/ha), which was closely followed by $\mathrm{P}_{7}(110.00 \mathrm{t} / \mathrm{ha})$. As regard stripped cane yield all planting patterns produced significantly different stripped cane yield in both crop years. During the years 2013-15, $\mathrm{P}_{1}$ produced maximum stripped cane yield (134.88 t/ha) followed by $\mathrm{P}_{2}$ (130.98 t/ha) in plant crop. The lowest stripped cane yield was noticed when sugarcane was sown in $\mathrm{P}_{7}$ (103.97 t/ha). The almost similar trend was observed in ratoon cane crop, while the highest stripped cane yield was detected in $\mathrm{P}_{1}(101.51 \mathrm{t} / \mathrm{ha})$. The minimum stripped cane yield (83.85 t/ha) was noticed in $\mathrm{P}_{8}$ and it was closely followed by $\mathrm{P}_{7}$ (85.07 t/ha). Overall stripped cane yield was higher in plant crop than ratoon crop.

The brix percentage, commercial cane sugar (CCS) and sugar recovery (SR) were non- significant during both plant and ratoon crop years (data not shown). However, brix percentage ranged from 21.52 to $22.08 \%$ and 22.13 to $22.27 \%$ for both plant and ratoon crops, respectively. CCS percentage ranged from 13.34 to 13.50 for plant crop and 13.78 to 13.94 for ratoon crop. SR ranged from 12.54 to $12.69 \%$ and 12.97 to $13.10 \%$ for plant and ratoon crop, respectively.

Effects of pit planting patterns on sugarcane economics: Averaged across two-years, net field benefits (NFB) of plant and ratoon crop of sugarcane (Table 4) showed that maximum NFB of Rs. 347819/ha in sowing pattern of $\mathrm{P}_{2}$, while the least NFB (Rs. 246239) were noted from $\mathrm{P}_{7}$. The economic analysis further revealed that during plant crop year, cost of production was more in square pit plantation than round pit plantation because square pit plantation is laborious that requires not only more time but also requires more labor for digging the pits that ultimately increased the variable cost of treatments. Whereas in round pit plantation, the only tractor mounted post hole digger was used for digging the pits. Reduction in NFB in round pits of sugarcane during ratoon crop year was mainly due to a reduction in stripped cane yield. Average benefit cost ratio (BCR) of both plant and ratoon crop of sugarcane is presented in Table 4. The maximum BCR (1.57) was achieved from $\mathrm{P}_{2}$ while least BCR (1.24) was noted in $\mathrm{P}_{7}$. The pooled data on dominance analysis and the marginal rate of returns (MRR) of plant and ratoon crop of sugarcane are presented in Table 5. Based on two-year average data, $\left(\mathrm{P}_{7}, \mathrm{P}_{5}, \mathrm{P}_{3}\right.$, and $\left.\mathrm{P}_{1}\right)$ were dominated. Those planting patterns which were signed as " $\mathrm{D}$ " in dominance analysis were not selected for marginal analysis. Maximum marginal rate of returns $(291 \%)$ was obtained from $\mathrm{P}_{2}$.

Table 5. Pooled dominance analysis and marginal rate of returns as affected by different pit planting patterns in plant and ratoon crop of sugarcane 2013-16 (each value is the average total experimental duration)

\begin{tabular}{lccrrr}
\hline $\begin{array}{l}\text { Planting } \\
\text { patterns }\end{array}$ & $\begin{array}{c}\text { Cost that } \\
\text { vary (Rs.) }\end{array}$ & $\begin{array}{c}\text { Net field } \\
\text { benefits } \\
\text { (Rs.) }\end{array}$ & \multicolumn{1}{c}{$\begin{array}{c}\text { Margina } \\
\text { l cost } \\
\text { (Rs.) }\end{array}$} & $\begin{array}{c}\text { Marginal MRR } \\
\text { net profit }\end{array}$ & $(\%)$ \\
\hline $\mathrm{P}_{8}$ & 104239 & 289389 & - & - & - \\
$\mathrm{P}_{6}$ & 119519 & 302881 & 15280 & 13492 & 88 \\
$\mathrm{P}_{4}$ & 127262 & 316382 & 7743 & 13501 & 174 \\
$\mathrm{P}_{2}$ & 138059 & 347819 & 10797 & 31437 & 291 \\
$\mathrm{P}_{7}$ & 143718 & $\mathrm{D}$ & 5658 & -101580 & $\mathrm{D}$ \\
$\mathrm{P}_{5}$ & 175819 & $\mathrm{D}$ & 32101 & 10654 & $\mathrm{D}$ \\
$\mathrm{P}_{3}$ & 189067 & $\mathrm{D}$ & 13248 & 9337 & $\mathrm{D}$ \\
$\mathrm{P}_{1}$ & 209338 & $\mathrm{D}$ & 20271 & 11986 & $\mathrm{D}$ \\
\hline
\end{tabular}




\section{Pit-planting of sugarcane}

\section{DISCUSSION}

Emergence count is directly involved in the index of crop formation, as plant population depends on emergence which is one of the important factors of yield. The non-significant results among different planting patterns were the usage of same seed rate and same environmental conditions in all pit systems of the plantation. These findings are confirmed by Aamer et al. (2017) also observed non-significant emergence percentage of the sugarcane planted under the different geometric arrangement. The taller plants in P7 are possibly due to a better distribution of resources (light, water, and nutrients). The similar findings were observed by Cheema et al. (2002) and Ehsanullah et al. (2011) who reported that a linear relationship for an increase in plant height was exhibited by greater seed-bed depth, lesser inter-plant competition, and proper spacing. The highest internodal length of sugarcane in $\mathrm{P}_{8}$ might be attributed to better crop growth rate during the entire crop growing period and better utilization of the farm inputs resources due to less plant to plant competition. Our results related to the length of internodes are in line with those reported by Aamer et al. (2017) who found a significant difference in the internodal length of a cane due to various planting patterns.

More cane girth at $90 \mathrm{~cm}$ parts pits was attributed to several reasons viz., more nutrient availability and the subsequent uptake, more availability of the photosynthetically active radiation (PAR) and less lodging losses due to proper anchorage and circulation of air. Greater biomass/un-stripped cane yield in $\mathrm{P}_{1}$ was ascribed to more number of tillers and millable canes per unit area and better physiological performance of cane crop. These findings are validated by Bashir et al. (2005). Sugarcane stripped cane yield mainly depends on stand density, cane length and diameter, and the millable canes $/ \mathrm{m}^{2}$. The significant higher stripped cane yield in $\mathrm{P}_{1}$ might be because of more number of millable cane $/ \mathrm{m}^{2}$ and more unstripped cane. Bull and Bull (2000) reported that in the climatic conditions of Australia, up to $60 \mathrm{t} / \mathrm{ha}$ of stripped cane yield increased in narrow rows as compared to wider row spacing.

The non-significant differences among different planting patterns regarding brix percentage, CCS, and sugar recovery might be due to the similar varietal character (Tej et al., 2006; Jain et al., 2002; Ali et al., 2001). Moreover, Chattha et al. (2007) observed that cane planted under different planting techniques also observed no difference in sugarcane quality attributes.

Conclusions: The present study demonstrated that round pits performed best in terms of economic return compared to square pit plantation. $45 \mathrm{~cm}$ spaced round pits having a diameter of $90 \mathrm{~cm}$ gave maximum net field benefits (Rs. 347819/ha) and with BCR of 1.57. Although square pit planting provided more yield because of increasing variable cost of production, reduction in net field benefits was observed. Under the prevailing circumstances, farmers with small land holdings should preferably adopt round pit plantation for sugarcane crop because, in square pits planting, higher labour cost is involved in digging the pits manually.

\section{REFERENCES}

Aamer, M., R. Ahmad, S.A. Anjum, M.U. Hassan, F. Rasul. W. Zhiqiang, H.Z.U. Qasim, F.A. Chaudhary and H. Guoqin. 2017. Production potential of ratton crop of sugarcane planted under varying planting dimensions. Acad. J. Agric. Res. 5:39-44.

Ahmad, J., M.K. Javed, M. Nazam and M. Nazim. 2014. Research on factors influencing the sugarcane production in Pakistan: A case study of Punjab. In: J. Xu, V. CruzMachado, B. Lev and S. Nickel (eds.), Advances in Intelligent Systems and Computing, Vol. 281, p.13731384. Proceedings of the Eighth International Conference on Management Science and Engineering Management. Springer, Berlin.

Ali, F.G., M. Akhtar, M. Saeed and S. Afghan. 2001. Effect of planting methods and weed management on cane quality and quality parameters in spring cane. Pak. Sugar. J. 16: 15-17.

Bashir, S., A.A. Chattha, M. Yasin and Z. Mahmood. 2005. Sugarcane varieties and row spacing effect on sugarcane traits. Pak. Sugar. J. 20:18-20.

Bull, T.A. and J.K. Bull. 2000. High density planting as an economic production strategy: (b) theory and trial results. In: D.M. Hogarth (ed.), Proceedings of the 2000 Conference of the Australian Society of Sugar cane Technologists held at Bundaberg, Queensland, Australia, May 2-5, 2000; pp.119-125.

Chand, M., A. Khippal, S. Singh, R. Lal and R. Singh. 2011. Effect of planting material and seed rate in pit planted sugarcane (Saccharum spp. hybrid complex) in subtropical India. Ind. J. Agron. 56:78-82.

Chattha, M.U. and Ehsanullah. 2003. Agro-quantitative and qualitative performance of different cultivars and strains of sugarcane (Saccharum officinarum L.). Pak. Sugar. J. $18: 2-5$.

Chattha, M.U., A. Ali and M. Bilal. 2007. Influence of planting techniques on growth and yield of spring planted sugarcane (Saccharum officinarum L.). Pak. J. Agri. Sci. 44:452-455.

Cheema, I.A., M. Ayub and A. Jabbar. 2002. Bio economic efficiency of spring planted sugarcane as influenced by spatial arrangement and nutrient management. Pak. Sugar. J. 17:62-68.

CIMMYT. 1988. From agronomic data to farmers recommendations: An economics training manual. CIMMYT, Mexico, D.F. 
Ehsanullah, K. Jabran, M. Jamil and A. Ghaffar. 2011. Optimizing the sugarcane row spacing and seeding density to improve its yield and quality. Crop Environ. 2:1-5.

FAO Stat. 2012. Statistical Database. Food and Agriculture Organization (FAO). Available online with updates at www.faostat.fao.org.

Govt. of Pakistan. 2016. Economic Survey of Pakistan. 201516. The government of Pakistan, Economic Affairs Division, Ministry of Finance, Islamabad, Pakistan.

Ghaffar, A., Ehsanullah, N. Akbar and S.H. Khan. 2011. Influence of zinc and iron on yield and quality of sugarcane planted under various trench spacings. Pak. J. Agri. Sci. 48:25-33.

Jain, P., R. Pal, S.P. Kadian and M.L. Saini. 2002. Character relationship among quality and agronomical traits in sugarcane. Ind. Sugar. 52:723-726.

Maqsood, M., M. Iqbal and M. Tayyab. 2005. Comparative productivity performance of sugarcane (Saccharum officinarum L.) sown in different planting patterns at farmer's field. Pak. J. Agric. Sci. 42:25-28.

Nazir, A., G.A. Jariko and M.A. Juejo. 2013. Factors affecting sugarcane production in Pakistan. Pak. J. Commer. Soc. Sci. 7:128-140.
Rehman, A. and Ehsanullah. 2008. Increasing yield of ratoon sugarcane. Available online with updates at http://www.dawn.com/news/296976/increasing-yieldof-ratoon-sugarcane

Shukla, S.K., M. Lal and S.K. Singh. 2013. Improving bud sprouting, growth and yield of winter initiated sugarcane ratoon through tillage cum organic mediated rhizospheric modulation in Udic ustochrept under subtropical Indian condition. Soil Tillage Res. 126:50-59.

Singh, N., J.L. Jain and D.K. Singh. 2009. Impact of planting techniques on sugarcane and sugar productivity at Harinagar, Bihar. Ind. Sugar. 59:19-22.

Spancer, G.L. and G.P. Meade. 1963. Cane sugar handbook, $9^{\text {th }}$ Ed. John Wiley and Sons, Inc. New York, USA.

Steel, R.G.D., J.H. Torrie and D.A. Dicky. 1996. Principles and Procedures of Statistics: A biometrical approach, $3^{\text {rd }}$ Ed. McGraw Hill, Inc. Book Co. NY, USA.

Sureka, B.K., V.P. Shahi, I.S. Singh and N. Singh. 2009. Ring pit planting technique of sugarcane adopted to increase cane productivity at Bharat sugar mills, Sidhwalia, Gopalganj Bihar. Ind. Sugar. 59:69-74.

Tej, P., R. Singh and P.P. Singh. 2006. Studies on the effect of row spacing, seed rate and fertility levels on growth and yield of sugarcane (Saccharum officinarum L.). Ind. Sugar. 56:29-34. 